\title{
Café e chá na representação visual europeia, 1640-1790
}

\section{Coffee and tea in the European visual representation, 1640-1790}

Nicole Leite Bianchini ${ }^{1}$

O propósito desta apresentação será o de expor, em linhas gerais, os primeiros resultados de uma pesquisa de mestrado, iniciada em 2017, acerca das representações visuais do consumo de café e de chá. O escopo deste trabalho foram as imagens produzidas em torno destas bebidas a partir dos primeiros registros de seu consumo em torno da década de 1640, dentro do noroeste europeu, até a sua completa assimilação ao cotidiano desta região, que compreende Inglaterra, França e Províncias Unidas, na virada para o século XIX.

Diante da extensão temporal e geográfica proposta, foram usadas as coleções digitalizadas de inúmeros museus, bibliotecas e arquivos, das quais foram reunidas quase duzentas imagens pertinentes ao tema. Na sequência, tais imagens foram reunidas em séries temáticas, que por sua vez poderiam ser analisadas em busca de padrões de representação, escolhas materiais, composição interna e aspectos de sua produção. Paralelo à análise destas séries, o discurso em torno do consumo destas novas bebidas exóticas também foi reunido e revisto a partir das fontes escritas mais utilizadas em torno da bibliografia especializada. Foram reunidos, neste âmbito, documentos como tratados em torno destas bebidas, narrativas de viajantes, propagandas, manuais de bons modos e comportamento direcionados tanto ao público masculino quanto ao feminino, e periódicos.

A pesquisa realizada, assim, se enquadra em uma diversidade de campos historiográficos, atuando dentro da história social e econômica ao passo em que entende as commodities enquanto objetos que compreendem tanto as estruturas de produção e circulação quanto de consumo. $\mathrm{O}$ estudo do aspecto visual deste mundo tem por objetivo intervir em uma fortuna historiográfica que ora se debruça somente pelos aspectos econômicos do mercado de commodities moderno, ora se dedica somente aos estudos dos padrões e significados do seu consumo no mundo europeu, entendendo a visualidade como uma fonte privilegiada para observar o encontro destas duas esferas. Dentro dos estudos sobre história da alimentação, a proposta foi agrupar a dimensão material do café e do chá com o seu aspecto mental enquanto símbolo visual adotado por pintores e gravadores.

A partir do diálogo entre as fontes escritas e visuais, então, foi possível delimitar três momentos distintos no processo de longa duração da incorporação do consumo de bebidas quentes ao cotidiano urbano europeu. Partindo da ideia de "aglomerados de consumo", que são definidos por Jan de Vries como conjuntos de artigos que têm significados específicos que seus componentes em separado não possuem, foi possível pensar a visualidade do café e do chá ao longo desta transformação.

Palavras-chave: café; chá; representação visual; consumo.

Keywords: coffee; tea; visual representation; consumption.

1 Mestranda em História Social na Universidade de São Paulo, bolsista CNPq, integrante do Laboratório de Estudos sobre o Brasil e o Sistema Mundial (LabMundi-USP) e pesquisadora do Laboratório de Estudos Históricos das Drogas e da Alimentação (LEHDA-USP). 